\title{
KEDUDUKAN ADVOKAT DALAM PASAL 5 UNDANG- UNDANG NOMOR 18 TAHUN 2003 TENTANG ADVOKAT PERSPEKTIF HUKUM
}

\author{
Adib khoirul umam \\ Fakultas Syariah Universitas Islam Negeri Maulana Malik Ibrahim \\ Email : adib270171@gmail.com
}

\begin{abstract}
Abstrak
This study aims to determine how Islam views which in this case is limited only four schools of opinion about the position of an advocate as law enforcement. In Islam indeed advocates known as providers of legal bantuah namely Hakam, mufti and mashalih alaih that functions similar to advokat.Penelitian function is called normative research with descriptive methods comparative analysis between positive law and Islamic law, namely Law No. 182003 and scholarly opinion four schools as primary data. Secondary data were taken from books or books that explain the legal theory of primary data. Article 5 of Law No. 18 of 2003 on lawyers has been explained that the position of advocate parallel with other law enforcement such as judges, prosecutors and police. But in fact appear black advocates not to enforce the law but instead became mafias that sell traded equity law. For it will be studied how exactly Islam's view of the position of Advocates with the formulation of the problem sebegai follows, first how the views of Islamic law for the position of advocate in Article 5 of Law No. 18 of 2003 on advocates, who both like where the relevance of Islam's view of the position of advocate in enforcement law in Indonesia. From research conducted authors argue for their refisi against the law number 18 of 2003 on advocates. alignment between advocates and other law enforcement must be followed by the high quality of an advocate and supervision of the performance of lawyers in order to minimize the occurrence of fraud in practice in providing legal aid.

Penelitian ini bertujuan untuk mengetahui bagaimana pandangan Islam yang dalam hal ini hanya dibatasi pendapat empat madzhab tentang kedudukan advokat sebagai penegak hukum. Dalam Islam memang advokat dikenal sebagai lembaga pemberi bantuah hukum yaitu hakam, mufti dan mashalih alaih yang secara fungsi hampir sama dengan fungsi advokat.Penelitian ini disebut penelitian normatif dengan metode deskriptif analisis perbandingan antara hukum positif dan hukum Islam, yaitu undang-undang nomor 18 tahun 2003 dan pendapat ulama empat madzhab sebagai data primer. Data sekunder diambil dari kitab-kitab atau bukubuku teori hukum yang menjelaskan tentang data primer. Dari penelitian yang dilakukan penulis berpendapat perlunya adanya refisi terhadap undang-undang nomor 18 tahun 2003 tentang advokat. kesejajaran antara advokat dan penegak hukum lainya harus diikuti dengan tingginya kualitas seorang advokat dan pengawasan terhadap kinerja advokat agar bisa meminimalisir terjadinya penyelewengan dalam praktiknya dalam memberi bantuan hukum.
\end{abstract}

Kata kunci; Advokat, Undang-undang, hukum Islam 
Advokat atau penasehat hukum adalah profesi pemberi bantuan hukum yang sudah tidak asing lagi di mata masyarakat. Profesi ini sudah ada di Indonesia sejak zaman kolonialisme yang tergabung dalam organisasi advokat yang disebut Balie van Advokaten. Saat itu advokat hanya terdapat di wilayahwilayah yang ada Landrat (pengadilan negeri) dan raad van Justice (dewan pengadilan). ${ }^{1}$ Sejak zaman Belanda hingga sekarang profesi ini keberadaanya di Indonesia sudah sangat dikenal di masyarakat awam maupun para ahli hukum. Karena itulah kenapa profesi ini sangat sering dibahas terlepas dari pro dan kontra yang ada dalam masyarakat.

Eksistensi Advokat di Indonesia kini sudah mulai kuat sejak munculnya undangundang nomor 18 Tahun 2003. Dikatakan demikian karena dalam undang-undang ini disebutkan bahwa organisai advokat berhak mengangkat advokat secara sendiri. Sebelumnya profesi-profesi pemberi bantuan hukum itu masih terkotak-kotak, ada yang disebut konsultan hukum, ada juga pengacara dan juga penasehat hukum, namun sekarang dalam undang-undang ini semua profesi itu disebut dengan nama advokat. Selain itu dalam undang-undang ini juga menegaskan kedudukan advokat di mata hukum adalah sebagai penegak hukum yang sejajar dengan penegak hukum yang lainya yaitu hakim, jaksa dan polisi, sebagai mana dalam pasal 5 yang bunyi pasalnya sebagai berikut:

"Advokat berstatus sebagai penegak hukum, bebas dan mandiri yang dijamin oleh hukum dan peraturan perundangundangan."

Kelebihan dari profesi advokat ini yang sarat dengan moral dan idealisme, sebenarnya terdapat banyak kontroversi dalam profesi ini. Menurut pendapat Darji Darmodiharjo dan Shidarta, ${ }^{2}$ profesi advokat ini banyak menimbulkan pro dan kontra. Bukan hanya terjadi di negara berkembang saja namun di negara maju juga merasakan tentang hal tersebut. Di Negara Amerika misalnya banyak survei menerangkan bahwa para pemimpin dunia berangkat dari

\footnotetext{
${ }^{1}$ V. Harlen Sinaga, Dasar-Dasar profesi Advokat, (Jakarta: PT. Gelora Aksara Pratama, 2011), 7

${ }^{2}$ Darji Darmodiharjo dan Shidarta, Pokok-pokok Filsafat Hukum, (Jakarta: PT. Gramedia Utama, 2000), 294-295
}

profesi advokat, selain cerdas dan rasional advokat terkenal orang yang pandai berdialektika. Namun di sisi lain banyak orang yang berpendapat bahwa profesi ini adalah profesi seseorang yang suka memutarbalikkan fakta, membuat samar permasalahan yang sudah jelas, dan dikatakan tidak bermoral karena membela orang-oranag yang bersalah yang seharusnya dihukum berat karena kesalahannya menjadi ringan atau bahkan terbebas dari jeratan hukum. Bahkan beberapa orang juga berpendapat bahwa profesi advokat itu bukan sebagai agent of law development atau agent of law enculturation tetapi menjadi agent of law commercialization karena mereka mengambil keuntungan dari penderitaan klien yang sedang terjerat masalah hukum. ${ }^{3}$

Di Indonesia komentar-komentar miring ini juga berkembang. Banyak orang yang beranggapan bahwa profesi advokat ini adalah profesi hitam dan tidak disukai, walaupun penyimpangan ini hanya dilakukan oleh segelintir orang yang berprofesi advokat tetapi imbasnya di masyarakat sangat kuat. Rahmat Rosyadi dan Sri Hartati berpendapat, ${ }^{4}$ pelaku penyimpangan dalam profesi ini bukan sekedar isu dan bukan merupakan rahasia lagi, tetapi sudah menjadi kenyataan dalam praktiknya di tengah masyarakat. Di media massa seringkali kita disuguhkan ulah para advokat yang terkesan membantu oknumoknum yang bersalah lepas dari jeratan hukum hingga melakukan penyuapan terhadap hakimhakim pengadilan.

Hasil survey LSI (Lembaga Survey Indonesa) bulan april 2013 menyebutkan tentang kepuasan masyarakat terhadap penegakan hukum di Indonesia menunjukkan 56\% menyatakan tidak puas, dan hanya $29,8 \%$ yang puas. ${ }^{5}$ Ketua yayasan Yap Thiam Hien yang juga ketua umum Ikatan Advokat Indonesia (Ikadin) Todung Mulya Lubis mengatakan bahwa hancurnya penegakkan hukum di negeri ini bukan hanya disebabkan oleh pelanggaran para penegak hukum, tapi juga karena makin

\footnotetext{
${ }^{3}$ Rahmad Rosyadi dan Siti Hartati, Advokat dalam Perspektif Islam dan Hukum Positif, (Jakarta: Ghalia Indonesa, 2002), 18

${ }^{4}$ Rahmad Rosyadi dan Siti Hartati, Advokat..18

${ }^{5}$ Survey LSI, "Kepuasan Masyarakat terhadap kinerja penegak hukum”, www.antikorupsi.org, diakses tanggal 25 Januari 2014
} 
bertambahnya advokat hitam yang terlibat dalam mafia hukum ${ }^{6}$. Beberapa waktu lalu kita dihadapkan dengan beberapa berita tentang dua pengacara menjadi tersangka dan ditahan karena diduga terlibat makelar kasus dan suap terhadap penegak hukum. Advokat Haposan Hutagalung yang menjadi kuasa hukum pegawai Direktorat Jenderal Pajak Kementerian Keuangan yakni Gayus HP Tambunan, menjadi tersangka dan ditahan Polri karena diduga terlibat merekayasa kasus yang menjerat kliennya. Pengacara Adner Sirait menjadi tersangka dan ditahan Komisi Pemberantasan Korupsi (KPK) karena diduga menyuap hakim Pengadilan Tinggi Tata Usaha Negara Jakarta. (sunber: Ibrahim. kompas, 7 April 2013). ${ }^{7}$

Sebuah fakta yang menarik jika kita sama-sama saksikan, di satu sisi pengacara adalah profesi yang keberadaannya sangat dibutuhkan karena diharapkan mampu memberikan pembelaan dan hak-hak hukum setiap warga negara, yang terkenal denga julukan officium nobile. Hukum positif di Indonesia (pasal 5 undang-undang nomor 18 tahun 2003) juga menetapkan kedudukan advokat sejajar dengan penegak hukum lainnya, yang artinya keberadaan advokat ini adalah sebuah keniscayaan untuk tegaknya hukum di Indonesia. Namun di sisi lain juga disebabkan oleh advokat bisa merusak tatanan kehidupan masyarakat, munculnya mafia peradilan dan tertutupnya fakta-fakta hukum sehingga semuanya menjadi samar dan tidak jelas.

Berdasarkan fakta yang terjadi di Indonesia, ada perbedaan antara bagaimana profesi advokat yang sesuai fungsi dan cita-cita bangsa ini dalam mewujudkan keadilan yang seadil-adilnya dengan praktik yang terjadi di masyarakat. Profesi advokat menjadi profesi kontroversial yang keberadaannya sering kali malah memberikan dampak negatif dalam proses penegakkan hukum. Masalah ini menjadi lebih menghawatirkan setelah adanya

\footnotetext{
${ }^{6}$ Suara Pembaharuan, "Jumlah Advokat di Indonesa Makin Banyak, Penegakan Hukum di Indonesia Hancur"

http://www.suarapembaruan.com/home/jumlah-advokathitam-makin-banyak-penegakan-hukum-di-indonesiahancur/35996 diakses tanggal 29 Januari 2014.

${ }^{7}$ Ibrahim, Harian Kompas Edisi 7 April 2013
}

undang-undang yang menyatakan bahwa kedudukan advokat sejajar dengan penegak hukum lainnya, yang berarti bahwa posisi advokat akan sama kuatnya dengan penegak hukum lain. Karena kehawatiran itulah menjadi perlu kita kaji bagaimana sistem hukum Islam mengatur tentang kedudukan advokat tersebut serta membandingkan relevansi penetapan kedudukan profesi ini untuk terwujudnya aturan-aturan yang lebih baik utamanya dalam mewujudkan keadilan yang seadil adilnya sesuai cita-cita kita bersama.

Undang-undang advokat nomor 18 tahun 2003 menjelaskan bahwa yang bisa menjadi seorang advokat bukan hanya alumni fakultas hukum tetapi alumni fakultas hukum Islam atau syariah. Berdasarkan hal tersebut maka menjadi penting untuk diketahui bagaimana hukum Islam itu mengatur keberadaan advokat dalam proses peradilan, baik secara fungsi maupun kedudukannya. Karena dalam agama Islam sebagai agama yang syumul juga mengatur sistem peradilan dalam upaya mendapatkan keadilan yang seadil-adilnya.

\section{TINJAUAN PUSTAKA}

\section{Pengertian Advokat}

Advokat, secara etimologi (bahasa) berasal dari bahasa latin yaitu advocare, yang artinya to defend, to call to one's aid to vouch or warrant maksudnya untuk pembeleaan, memanggil seseorang untuk dimintai bantuan agar bisa menuntut dan memberi jaminan. Sedangkan dalam bahasa Inggris advocate berarti: to speak in favour of or depend by argument, to support, indicate, or recommended publicly. ${ }^{8}$

Secara terminologis (istilah), advokat banyak didefinisikan oleh ahli hukum. Yudha Pandu berpendapat bahwa advokat adalah orang yang mewakili kliennya untuk melakukan tindakan sesuai kuasa yang diberikan untuk berpendapat melakukan pembelaan dan penuntutan dalam persidangan. ${ }^{9}$

\footnotetext{
${ }^{8}$ Frans Hendra Winarta, Advokat Indonesia Citra, Idealisme dan Keprihatinan, (Jakarta, Sinar Harapan, 1995), 19

${ }^{9}$ Yudha Pandu, Klien dan Penasehat Hukum dalam Perspektif Masa Kini (Jakarta, PT. Abadi Jaya, 2001). 11
} 
Kata advokat sesungguhnya sudah dikenal sejak abad pertengahan (abad ke 5-15), yang dikenal sebagai advokat geerja (kerkelijke advocaten, duivel advocaten), yaitu advokat ini bertugas memberikan keberatan-keberatan dan memberikan nasihat saat perayaan suci bagi orang yang telah meninggal. ${ }^{10}$

Di Indonesia pengertian advokat terdapat pada Undang-Undang Nomor 18 tahun 2003 tentang Advokat, yang berbunyi sebagai berkut:

"Advokat adalah yang berprofesi memberikan jasa hukum baik di dalam maupun di luar pengadilan yang memenuhi persyaratan berdasarkan ketentuan Undang-undang ini”

Dari beberapa penjelasan di atas dapat disimpulkan bahwa pengertian advokat adalah seseorang yang berprofesi memberikan bantuan, konsultasi Hukum baik di dalam mau-pun di luar pengadilan. Jadi semua orang yang berprofesi sebagai memberikan konsultasi atau bantuan bantuan hukum berupa apapun baik di dalam maupun di luar pengadilan disebut sebagai advokat.

\section{Peran dan fungsi Advokat}

Advokat sebagai profesi yang mendapat gelar officium nobile yaitu gelar yang sangat mulia, karena membela semua orang tampa membedakan latar belakang ras, agama atau status sosial lain yang ada di dalam masyarakat. Advokat wajib memberikan bantuan hukum kepada semua klien dengan seadiladilnya untuk membantu menciptakan keadilan dalam proses penegakkan hukum di Indonesia.

Menurut Ropaum Rambe advokat bukan hanya sekedar profesi untuk mendapatkan nafkah, tetapi juga harus memperjuangkan idealisme dan moralitas yang di dalamnya ada nilai kebenaran dan keadilan. ${ }^{11}$ Oleh karena itu sebagai seorang advokat, seseorang harus mempunyai standar idealisme dan moralitas yang kuat sehingga keberadaannya mampu memberikan kemaslahatan bagi proses penegakkan hukum di Indonesia.

\footnotetext{
${ }^{10}$ V. Harlen Sinaga, Dasa-Dasar. 2

${ }^{11}$ Rampau Rampe, Teknik Praktek Advokat, (Jakarta, Gramedia Widiasarana Indonesia, 2001), 33
}

Dalam pasal 7 Universal Declaration of Human Right menjelaskan bahwa setiap orang berhak atas perlindungan hukum yang sama dan tak ada perbedaan apapun satu dengan yang lainnya ${ }^{12}$.Konstitusi di Indonesia juga menjamin dalam pasal 27 Undang-Undang Dasar 1945 yang menyebutkan bahwa, semua warga Negara sama kedudukannya di mata hukum dan pemerintahan serta menjunjung hukum dan pemerintahan itu tanpa pengecualian. Oleh karena itu memberi pembelaan kepada semua masyarakat yang membutuhkan tanpa pandang bulu itu sudah menjadi kewajiban bagi seorang advokat.

Dalam Undang-Undang nomor 18 tahun 2003 tentang advokat pasal 1 ayat 1 menjelaskan peran dan fungsi advokat yang berbunyi sebagai berikut:

"Advokat adalah orang yang berprofesi memberikan jasa hukum baik di dalam maupun diluar pengadilan yang memenuhi persyaratan berdasarkan ketentuan undang-undang ini."

Dari pasal di atas dapat diketahui bahwah fungsi advokat adalah memberikan bantuan hukum kepada klien yang telah membutuhkan. Bantuan ini bisa dilakukan di dalam pengadilan maupun di luar pengadilan.

V. Harlen Sinaga berpendapat bahwa fungsi dan peran advokat ini harus mencakup seluruh masalah hukum baik itu hukum publik (public law) yaitu permasalahann hukum antara negara dengan warganya dan hukum perdata (private law) yaitu hukum yang mengatur hak dan kewajiban orang perorangan dan korporasi. $^{13}$

\section{Kewenangan Advokat}

Dalam sistem penegakkan hukum di Indonesia masing-masing penegak hukum sudah mempunyai tugas dan wewenang masing-masing. Seperti polisi bertugas di bidang penyelidikam dan penyidikan, jaksa bertugas penuntutan, hakim bertugas memutuskan sebuah perkara sedngkam advokata

\footnotetext{
${ }^{12}$ Ishaq, Pendidikan Keadvokatan, (Jakarta, Sinar Grafika, 2010), 41

${ }^{13}$ V. Harlen Sinaga, Dasa-Dasar. 20
} 
berada pada posisi berpihak kepada masyarakat (klien). ${ }^{14}$

Jadi advokat bertugas dan berwenang membantu klien untuk mendapatkan pembelaan dan bantuan hukum dalam rangka untuk mendapatkan keadilan yang seadil-adilnya. Untuk itu seorang advokat dalam menjalankan tugasnya harus memegang pada prinsip equality before the law (kesejajaran di mata hukum) dan prinsip presumption of innocene (Praduga tidak bersalah), sehingga dalam melaksanakan tugasnya seorang advokat melakukannya dengan obyektif.

Seperti yang telah disebutkan di atas bahwa dalam pasal 1 ayat 1 undang-undang nomor 18 tahun 2003 tentang keadvokatan menjelaskan bahwa dalam pelaksanaan tugasnya advokat meliputi pekerjaan baik yang dilakukan di dalam pengadilan (litigasi) maupun diluar pengadilan (non-litigasi). Pekerjaan dalam pengadilan yang dimaksud adalah segala bentuk bantuan hukum yang diberikan oleh advokat kepada kliennya yang itu dilakukan di dalam proses persidangan. Pekerjaan di luar pengadilan yang dimaksud adalah segala bentuk bantuan yang dilakukan di luar pengadilan seperti konsultasi, mediasi dan yang lainnya.

\section{Kedudukan advokat}

Dalam sistem penegakkan hukum di Indonesia dikenal lembaga-lembaga penegak hukum yaitu lembaga kepolisian, kejaksaan dan hakim seperti yang telah dijelaskan sebelumnya. Namun sejak adanya undang-undang nomor 18 tahun 2003 semunya telah berubah, Advokat yang dulu dalam peranya memberi bantuan hukum kepada klien sering dianggap sebelah mata oleh penegak hukum lain kini eksistensinya sudah mulai naik.

Ketentuan Pasal 5 Ayat (1) undang-undang Advokat memberikan status kepada advokat sebagai penegak hukum yang mempunyai kedudukan setara dengan penegak hukum lainnya dalam menegakkan hukum dan kea-dilan. Berikut ini bunyi pasal 5 undang-undang nomor 18 tahun 2003 tentang advokat

\footnotetext{
${ }^{14}$ Ishaq, Pendidikan keadvokatan, (Jakarta : Sinar Grafika, 2010), 36
}

"Advokat berstatus sebagai penegak hukum, bebas dan mandiri yang dijamin oleh hukum dan peraturan perundangundangan"

Dalam penjelasan undang-undang advokat menerangkan bahwa yang dimaksud dengan pasal 5 ayat (1) diatas adalah advokat sebagai salah satu perangkat dalam proses peradilan yang mempunyai kedudukan setara dengan penegak hukum lainya dalam menjalankan fungsinya untuk menegakkan hukum dan keadilan.

Kedudukan tersebut memerlukan suatu organisasi yang merupakan satu-satunya wadah profesi advokat sebagaimana dimaksud dalam Pasal 28 Ayat (1) undang-undang advokat, yaitu organisasi advokat merupakan satusatunya wadah profesi advokat yang bebas dan mandiri yang dibentuk sesuai dengan ketentuan undang-undang ini dengan maksud dan tujuan untuk meningkatkan kualitas profesi advokat. Oleh karena itu, organisasi advokat, yaitu PERADI, pada dasarnya adalah organ negara dalam arti luas yang bersifat mandiri (independent state organ) yang juga melaksanakan fungsi negara. ${ }^{15}$

Kalau diselidiki lebih jauh, baik secara normatif maupun dalam kenyataan lembaga penegak hukum tidak hanya terdiri dari tiga lingkungan jabatan tersebut di atas, bahkan dari perspektif pemecahan masalah dan pembaharuan penegak hukum, kalau hanya disebut tiga lingkungan jabatan tersebut, bukan saja tidak lengkap tetapi menyebabkan bias. Jika kita kaji dari sisi komponen kelembagaan penegak hukum, komponen utama lembaga atau kelembagaan penegak hukum dapat dibedakan menjadi dua kelompok yaitu, kelompok pro yustitia, dan kelompok non pro justitia, kelompok pro justitia dibedakan antara pro justitia murni dan tidak murni. Kelompok pro justitia murni terdiri dari lingkungan jabatan kepolisian (polisi), kejaksaan (jaksa penuntut umum), pengadilan (hakim). Tiga lingkungan jabatan ini merupakan kesatuan penegak hukum dalam rangkaian proses peradilan. Sedangkan kelompok pro justitia

\footnotetext{
${ }^{15}$ Lihat Pertimbangan Hukum Putusan MK Nomor 014/PUU-IV/2006 mengenai Pengujian Undang-Undang Advokat
} 
tidak murni adalah lembaga peradilan semu "quasi administratie rechpraak". Sebelum dihapus, kelompok ini mencakup juga badanbadan lain seperti Panitia Penyelesaian Perselisihan Hubungan Perburuhan, dan lain sebagainya. Lembaga penegak hukum non pro justitia dapat dibedakan antara kelembagaan dalam lingkungan pemerintahan dan di luar pemerintahan. Dalam lingkungan pemerintahan adalah lingkungan jabatan administrasi negara yang memiliki atau diberi wewenang polisionil, termasuk jabatan keimigrasian, bea cukai, perpajakan dan lain-lain. Sedangkan lembaga penegak hukum di luar pemerintahan adalah badan-badan yang diselenggarakan oleh masyarakat seperti advokat, notaris, mediasi, arbitrase, dan berbagai lembaga yang ada diberi wewenang menyelesaikan sengketa yang bersifat perdamaian. ${ }^{16}$

Jadi setelah keberadan pasal 5 undangundang nomer 18 tahun 2003 tentang advokat, maka kedudukan advokat sama seperti lembaga penegak hukum lainya seperti hakim, jaksa dan polisi. advokat adalah lembaga penegak hukum yang bebas dan independen karena tidak digaji oleh negara. Hal ini di tegaskan juga dalam pasal 14 undang-undang advokat.

Dalam Islam sesungguhnya kata advokat dikenal sebagai pemberi bantuan hukum. jika dilihat dari pengertian dan fungsinya sebagai pemberi bantuan hukum maka dalam islam juga mengenal lembaga pemberi bantuan hukum yang secara praktiknya juga sama yang dilakukan oleh para advokat. Karena kesamaan lemaga-lembaga pemberi bantuan hukum itulah sering dijadikan alasan para sarjana hukum untuk mempersamakan profesi advokat dengan lembaga penegak hukum dalam Islam

Ada tiga katagori profesi yang menjalankan tugas dan fungsi sebagai pemberi jasa hukum, yaitu hakam, mufti, dan mushalaih-alaih. ${ }^{17}$ Seperti yang telah di jelaskan di jelasan sebelumnya tentang

\footnotetext{
${ }^{16}$ Bagir Manan, Kedudukan Penegak hukum dalam sistem ketatanegaraan Republik Indonesia, Varia Peradilan ke XXI No.243 Februari 2006, hlm.7

${ }^{17}$ Rahmad Rosyadi dan Siti Hartati, Advokat dalam Perspektif Islam dan Hukum Positif, (Jakarta: Ghalia Indonesia, 2002), 38
}

pemberi bantuan hukum dalam Islam bahwa ketiga lembaga pemberi bantuan hukum ini fungsinya sama dengan advokat. Jasa hukum yang diberikan berupa konsultasi,menjalankan kuasa, mewakili, mendampingi, membela dan melakukan tindakan hukum lainya kepada klien untuk menyelesaikan perselisihan, mendamaikan sengketa atau memberikan nasehat kepada pihak yang bersengketa agar saling memenuhi hak dan kewajibanya masing-masing dan menyelesaikan sengketa secara damai.

Berdasarkan kesaman fungsi tersebut maka Rahmad Rosyadi dan Siti Hartati meqiyaskan atau mempersamakan istilah-istilah tersebut secara etimologis. ${ }^{18}$ Namun demikian tidak semuanya tepat di mata para ahli hukum dan bahkan menumbulkan perdebatan diantaranya, namun demikian jika kita lihat dan kita fahami bersama bahwa semangat dalam Islam untuk memberikan bantuan hukum baik di dalam maupun di luar peradilan oleh lembaga pemberi bantuan hukum dalam upaya untuk menegakkan keadilan yang sebenarbenarnya. Jadi advokat itu boleh keberadaanya dalam upaya untuk mewujudkan sistem peradilan yang seadiladilnya dalam masyarakat.

\section{TUJUAN PENELITIAN}

Berdasarkan rumusan masalah maka dalam pembahasan berikutnya perlu diketahui tentang tujuan dilakukannya penelitian ini. Adapun tujuan pertama penelitian ini adalah untuk memahami bagaimana pandangan Islam terhadap kedudukan advokat dalam pasal 5 undang-undang nomor 18 tahun 2003 dan yang kedua adalah Untuk memahami bagaimana relevansi pandangan Islam tentang advokat terhadap penegakkan hukum di Indonesia.

\section{Kedudukan Advokat dalam Hukum Islam}

Advokat sebagaimana yang telah dijelaskan dalam undang-undang advokat nomor

\footnotetext{
${ }^{18}$ Rahmad Rosyadi dan Siti Hartati, Advokat dalam Perspektif Islam dan Hukum Positif, 39
} 
18 tahun 2003 yaitu pemberi bantun hukum baik didalam maupun diluar pengadilan yang memenuhi syarat berdasarkan ketentuan undang-undang yang berlaku. Advokat merupakan pemberi jasa bantuan hukum yang independen diluar pemerintah berupa konsultasi, advokasi, kuasa dan sebagainya yang dilakukan terhadap klienya, baik didalam maupun diluar pengadilan. Jadi bisa dikatakan advokat adalah segala aktifitas pemberi bantuan hukum yang dilakukan terhadap orang yang sedang mengadapi masalah hukum dengan aturan dan ketentuan undang-undang yang berlaku.

Setelah adanya undang-undang advokat nomor 18 tahun 2003 pasal 5 kedudukan advokat juga semakin kuat sebagaimana bunyi pasal berikut:

"Advokat berstatus sebagai penegak hukum, bebas dan mandiri yang dijamin oleh hukum dan peraturan perundangundangan"

Dalam pasal 5 undang-undang advokat diatas telah dijelaskan bahwa kedudukan advokat itu sejajar dengan penegak hukum lainya seperti hakim, jaksa dan polisi. Pasal ini menegaskan bahwa kedudukan advokat sejajar dengan penegak hukum lain seperti Hakim, Jaksa dan kepolisian yang keberadaanya sudah tidak bisa dipandang sebelah mata lagi oleh penegak hukum lainya. Ruang gerak advokad juga semakin luas sejak disahkanya undang-undang tersebut karena advokat bisa beracara dimana saja tidak terbatas dalam suatu wilayah tertentu.

Berpicara advokat dalam hukum Islam seperti yang telah dijelaskan sebelumnya, bahwa dalam islam tidak mengenal kata advokat namun juga kita melihat secara fungsinya maka ahli hukum menyamakan posisi advokat di dalam Islam dengan pemberi jasa bantuan hukum seperti hakam, mufti, mushalih-alaih. Ketiga pemberi bantuan hukum tersebut secara fungsi hampir sama dengan fungsi advokat yaitu lembaga penegak hukum diluar pemerintah yang bertugas memberi jasa hukum kepada masyarakat.

Dalam pembahasan kali ini kita akan membahas tentang kedudukan advokat didalam hukum Islam. Islam tidak mengenal kata advokat namun ada lembaga pemberi bantuan hukum dalam Islam yang secara fungsi itu menye-rupai dengan fungsi advokat. Meskipun dalam persamaan ini mengundang banyak perselisihan nantinya namu penulis sepakat dengan pendapat ahli hukum yang mengqiyaskan advokat dengan lembega pem-beri bantuan hukum dalam Islam. Jadi dalam pembahasan ini kita akan mengkaji bagai mana kedudukan pemberi bantuan hukum dalam Islam, dan pendapat para ulama tentang keberadaan lembaga tersebut.

Lembaga hakam seperti yang telah dijelaskan dalam bab sebelumnya adalah pemberi bantuan hukum dalam Islam yang berada diluar pengadilan, bertugas menye-lesaikan perkara yang terjadi di tengah masyarakat. Namun keputusanya tidak ada keharusan untuk mengikutinya, karena pada dasarnya hanya keputusan hakim yang bisa diterima dan mempunyai kekuatan hukum yang tetap. Profesi hakam ini seperti halnya fungsi advokat yang harus bisa menjadi penengah setiap perkara sebelum perkara itu diajukan ke pengadilan.

Para ahli fiqih berpendapat bahwa seorang hakam itu seharunya orang yang memiliki syifat seperti hakim. ${ }^{19}$ Yaitu bisa dijadikan saksi baik itu laki-laki ataupun perempuan dan mempunyai keahlian dibidang hukum sehingga dalam praktiknya hakam bisa melakukan bantuan hukum dengan maksimal. Jadi pada dasarnya kualifikasai dari kualitas diri seorang hakam dan hakim sama. Para Imam Mazhab bersepakat bahwa syarat menjadi hakim adalah Berakal, baligh, merdeka, muslim, mendengar, bisa melihat dan mampu berbicara. Mereka berselisihkan hanya masalah adil, laki-laki dan perempuan, berijtihad. $^{20}$

Mazhab Maliki, Syafi'I dan Hambali menysyaratkan bahwa seorang hakim harus adil, karena itu tidak boleh mengangkat seseorang yang kesaksianya ditolak. Orang yang memiliki kriteria adil adalah meni-nggalkan dosa-dosa besar dan tidak terus menerus melakukan dosa kecil, akidahnya benar, menjaga kehormatan,dan tidak dicurigai menge-

\footnotetext{
${ }^{19}$ T.M Hasby As-Shiddieqy, Peradilan dan Hukum Acara Islam, PT Pustaka Rizki Pura, semarang 1997 hal. 71

${ }^{20}$ Wahbah Az-Zuhaili, Fikhul Islam waadilatuh terjemahan 106
} 
depankan kepentingan pribadi, atau mencegah kemudharatan dirinya dengan cara yang tidak dibenarkan agama. Mahzab Hanafi berpendapat boleh mengangkat hakim dari orang yang fasik jika dalam keadaan darurat. ${ }^{21}$

Tentang laki-laki dan perempuan seluruh imam mazhab bersepakat kecuali Imam Hanafi bahwa hakim harus laki-laki. Imam Hanafi berpendapat perempuan bisa menjadi seorang hakim dalam perkara sengketa harta dan keuangan. Ibnu Jarir berpendapat wanita bisa menjadi hakim secara mutlak. ${ }^{22}$ Tentang kemampuan berijtihad hakim mazhab Syafi'I, Maliki, Hambali dan sebagian ulama dari madzhab Hanafi mensyaratkan hakim harus mampu berijtihad. ${ }^{23}$ Madzhab Maliki mensyaratkan bahwa hakim harus seorang mijtahid namun mereka menerima hakim yang muqallid asalkan ada mujtahid. ${ }^{24}$

Dari penjelasan dan pendapat para Imam madzhab diatas penulis sepakat bahwa seorang hakim ataupun hakam sebagai pemberi bantuan harus seorang yang adil yaitu secara moral hakim atau hakam sebagai penegak hukum harus baik dan bisa dipercaya. Tentang penafsiran bias jender masalah memposisikan hakim ataupun hakam wanita, penulis sepakat dengan pendapat yang menyatakan bahwa wanita bisa juga menjadi seorang hakim atau hakam dengan syarat dia mampu dan mempunyai kompetensi dan keahlian sesuai yang telah ditetapkan sebagai penegak hukum.

Dalam islam juga mengenal pemberi jasa konsultasi hukum yaitu seorang mufti. Menurut Hasbi Ash Shiddieqy pada hakikatnya mufti adalah menyampaikan hukum Allah kepada umat manusia. ${ }^{25}$ Jadi tugas mufti adalam memberikan konsultasi atas hukum-hukum Allah kepada masyarakat yang membutuhkan. Fungsi mufti sebagai penasehat hukum ini

\footnotetext{
${ }^{21}$ Wahbah Az-Zuhaili , Fikhul Islam waadilatuh terjemahan 105-106

${ }^{22}$ Wahbah Az-Zuhaili, Fikhul Islam waadilatuh terjemahan 106-107

${ }^{23}$ Ibnu Rausyd, Bidayatul Mujtahid wa Nihayatul Muqtasid, Terjemahan oleh Imam Ghazali Said dan Ahmad Zaidun (Jakarta, PUSTAKA AMANI,2007) jilid III hal 678

${ }^{24}$ Wahbah Az-Zuhaili , Fikhul Islam waadilatuh terjemahan 108

25 T.M Hasby As-Shiddieqy, Peradilan dan Hukum Acara Islam, PT Pustaka Rizki Pura, semarang 1997 hal 73
}

seperti fungsi advokat sebagai penasehat hukum yaitu memberikan konsultasi atas sebuah perkara hukum yang dialami oleh klienya.

Untuk menjadi seorang mufti dalam islam dia harus seseorang yang terkenal benar, tingkah lakunya baik dan adil baik dalam perkataan maupun perbuatanya karena dia membawa dan menyampaikan hukum dari Allah SWT. Menurut Hasan Al-Bisri dan segolongan dari ulama usul berpendapat bahwa orang yang memberi fatwa harus orang mujtahid, namun pendapat yang paling kuat adalah boleh orang yang bukan mujtahid memberi fatwa asal dia bisa meneliti dali-dalil yang dipegang oleh imamnya. ${ }^{26}$ Syarat menjadi mufti harus bisa berijtihad ini sama dengan syarat menjadi seorang hakim yang mayoritas ulama mahzab terutama Mahzab Hanafi yang menjadikan syarat utama seorang hakim harus mampu berijtihad.

Untuk menjaga agar seorang yang meberikan fatwa adalah benar benar orang yang faham atas aturan hukum Allah maka dalam Islam juga mengaruskan adanya pengawasan terhadap kinerja para mufti yang dilakukan oleh Penguasa. Pengawasan ini untuk menjaga dan memastikan bahwa orang yang ingin mendapatkan fatwa benar benar bisa mendapat fatwa yang sesuai dengan aturan hukum Islam. Bahkan jika diketahui seorang yang tidak layak memberi fatwa namun dia memberikan fatwa maka orang tersebut harus dijatuhi hukuman. ${ }^{27}$

Dari keterangan tersebut sudah jelas seorang mufti harus benar-benar orang yang kefahaman yang mendalam terhadap aturan hukum yang berlaku sebagaimana seorang advokat saat meberikan konsultasi hukum harus benar-benar faham atas aturan hukum yang berlaku. Selain itu seorang dalm meberi bantuan hukum harus diawasi agar meminimalisir terjadinya penipuan ataupun kegiatan yang lain yang dapat merugikan kliennya dalam upaya mencari keadilan.

\footnotetext{
26 T.M Hasby As-Shiddieqy, Peradilan dan Hukum Acara Islam, PT Pustaka Rizki Pura, semarang 1997 hal. 75

27 T.M Hasby As-Shiddieqy, Peradilan dan Hukum Acara Islam, PT Pustaka Rizki Pura, semarang 1997 hal. 77
} 
Lembaga berikutnya pemberi bantuan hukum dalam Islam adalah Mushalih-alaih sebgaimana yang dijelaskan sebelumya mushali-alaih adalah pembantu pembut perjanjian agar kedua belah pihak bisa berdamai. ${ }^{28}$ Lembaga ini tugasnya adalah memberikan bantuan hukum berupa pembuatan perjanjian damai. Sesungguhnya bisa dibilang lebaga ini mengusahakan adanya perdamaian atara penggugat dan tergugat tanpa harus berada di meja pengadilan. Orang yang melakukan perdamaian adalah orang yang tindakanya dinyatakan sah secara hukum (cakap hukum) dan juga mengerti dan faham dengan hukum perjanjian yang akan dilakuan.

Sederhanya dari lembaga Musalih-alaih ini adalah pihak yang diberikuasa oleh orang yang berpekara untuk melakukan perjanjian damai atas sebuah perselisihan. Jika di kaitkan dengan fungsi advokat sebagai kuasa hukum, maka fungsi dari lembaga ini hampir sama dengan peran advokat sebagai kuasa hukum atas klienya untuk membantu membuat akta perjanjian.

Dari penjelasan lembaga -lembaga pemberi bantuan hukum tersebut dapat kita ketahui bawasanya keempat ulama madzahab sepakat bahwa pemberi jasa bantuan hukum itu sejajar dengan penegak hukum lainya meskipun berada diluar lembaga peradilan. Meskipun mempunyai wilayah tugas masing-masing dan tidak sama dengan tugas hakim sebagai penegak hukum, namun keempat ulama mahzab berpendapat bahwa kwalifikasi seorang penegak hukum itu harus sama dengan hakim sebagai penegak hukum utama dalam Islam.

Sebagaimana dalam pembahasan diatas, para ulama madzhab lebin menitik beratkan dalam persyaratan untuk menjadi seorang penegak hukum. Dalam Islam persyaratan untuk menjadi sorang peneak hukum sangatlah berat. Diantaranya yang paling utama adalah bahwa seorang penegak hukum itu harus seseorang yang adil. Pengertian adil menurut para ulama madzhab adalah yaitu orang tersebut tidak melakukan dosa besar dan juga senantiasa menghindari dosa kecil, menjaga kehormatan, bisa dipercaya dan tidak melakukan penyelewengan peraturan apa lagi untuk kepentingan pribadi. Bahkan jiga seseorang itu

\footnotetext{
${ }^{28}$ Sayyid Sabiq, Fikih Sunnah 13 (Terjemahan). (Bandung, PT. A Ma'arif 1987). 189
}

yang dicurigai telah melakukan suatu perbuatan dzalim dan belum terbukti maka tidak pantas orang tersebut menjadi penegak hukum. Selain kualitas intelektual dan kualitas moral penegak hukum, dalam Islam juga melakukan pengawasan terhadap kinerja para penegak hukum.

Jika kita melihat fakta yang terjadi di Indonesia banyak sekali berita miring, bahkan kasus pidana yang menjerat para penegak hukum kita. Beberapa waktu lalu seorang hakim mahkamah konstitusi tertangkap dan menjadi tersangka atas kasus penyuapan. Fakta yang terjadi dinegara ini adalah bukti bahwa dalam penyaringan dan pengangkatan seseorang menjadi penegak hukum belum maksimal.

Sebenarnya dalam aturan undang-undang advokat nomor 18 tahun 2003 itu sudah tepat karena memposisikan seorang advokat sebagai penegak hukum itu sudah sangat tepat, karena advokat akan bisa membantu proses penegakkan hukum dan menjamin hak-hak masyarakat. Dengan adanya advokat sebagai penegak hukum akan mampu memberikan advokasi masyarakat atas kedzaliman peme-rintah dalam hal penegakkan hukum. Namun kesejajaran ini harus di barengi dengan penjagaan kualitas advokat sebagai penegak hukum. Jika kita tidak memperhatikan dalam proses rekruitmen penegak hukum maka imbasnya malah akan menciptakan mafia-mafia hukum dalam masyarakat.

Selain memperketat penjagaan kualitas advokat sebagai penegak hukum, yang perlu dilakukan adalah sistem pengawasan terhadap praktik advokat. Hal ini juga dilakukan untuk meminimalisir terjadinya penyelewengan yang dilakukan oleh penegak huku. Kalau perlu malah diberikan sangsi yang berat terhadap para penegak hukum yang menyalahgunakan wewenangnya.

\section{Relevansi Pandangan Islam tentang Kedudukan Advokat dalam Sistem Penegakkan Hukum di Indonesia}

Dalam sistem hukum Indonesia, dikenal berbagai sumber hukum nasional yang berasal dari hukum adat, hukum Islam dan hukum barat. Ketiga sumber hukum tersebut selalu berlomba untuk mejadi hukum nasional sehingga berlakulah berbagai teori hukum. ${ }^{29}$

\footnotetext{
${ }^{29}$ A. Rahmat Rosyadi, dan H. M. Rais Ahmad, Formalisasi Syariat Islam dalam Perspektif Tata Hukum
} 
Sesungguhnya UUD 1945 sangat akomodatif terhadap kepentingan warga negara dalam menjalankan ibadahnya. Dalam perspektif tata hukum Indonesia, fungsi negara adalah melindungi setiap agama dan pemeluknya melalui peran menjamin pelaksanaan ibadah, memberikan dukungan fasilitas dan menjaga kerukunan antarumat beragama. Agama haruslah menjadi landasan moral, karenanya setiap peraturan dan perundang-undangan yang bertentangan dengan moral dan agama mesti dikesampingkan. Secara normatif, menjalankan syariat Islam secara kaffah merupakan perintah Allah, dan mengabaikannya dikategorikan sebagai manusia kafir, zalim, atau fasik.

Para ahli hukum di Indonesia mempelajari tentang teori-teori penerapan hukum Islam melalui sistem hukum yang pernah berlaku di Indonesia selama masa kolonial Belanda. Adanya teori-teori ini menggambarkan, betapa akrabnya hukum Islam dengan penduduk, masyarakat, dan bangsa Indonesia. Hal ini merupakan indikator bagaimana perjuangan masyarakat Indonesia yang beragama Islam ingin memberlakukan syariat Islam sesuai perintah Allah dan rasul-Nya. ${ }^{30}$

Membicarakan tentang teori-teori permberlakuan hukum Islam, maka akan sangat berkaitan dengan proses bagaimana unsurunsur hukum Islam itu dapat menjadi hukum positif atau bagian dari hukum nasional, disamping hukum adat dan hukum Barat. Adanya politisasi hukum yang dilakukan oleh kolonial Belanda ke arah mereduksi syariat Islam serta menjauhkan dari masyarakatnya, menyebabkan hukum Islam sampai saat ini selalu terpinggirkan dalam proses positivasi hukum dalam perspektif tata hukum Indonesia. $^{31}$

Ajaran Islam tentang penataan hukum memberi gambaran, bagaimana sesungguhnya Islam telah menata kehidupan manusia ini dengan hukum-hukum yang telah ditetapkan. Teori atau ajaran tentang penataan hukum

Indonesia, (Edisi: I, Ghalia Indonesia, Bogor, 2006), hal 9

${ }^{30}$ A. Rahmat Rosyadi, dan H. M. Rais Ahmad, Formalisasi Syariat Islam dalam Perspektif Tata Hukum Indonesia, hal 67

31 A. Rahmat Rosyadi, dan H. M. Rais Ahmad, Formalisasi Syariat Islam dalam Perspektif Tata Hukum Indonesia, hal, 68 menurut perspektif Islam bersumber dari Allah sebagai pencipta syariat dalam bentuk wahyu, yaitu al-Qur'an. Ia merupakan hukum normatif bersifat universal dan berlaku untuk seluruh manusia tanpa membedakan kedudukan, ras, politik, dan sosial-budaya. Keuniversalan hukum al-Qur'an itu memerlukan penjelasan dalam bentuk implementasi hukum yang bersifat praktis. Hal ini dilakukan Rasulullah melalui kehidupan sehari-hari, dalam bentuk hukum normatif bersifat aplikatif, yaitu AsSunnah. ${ }^{32}$ Manakalah terjadi ketiadaan atau ketidakjelasan hukum yang dimaksud oleh Allah dan rasul-Nya dalam al-Qur'an dan assunnah, maka pembentukan hukumnya diserahkan kepada manusia, melalui metode ijtihad.

Pandangan Islam tentang kedudukan advokat di Indonesia seperti yang telah dibahas sebelumnya bahwa para ulama mdzhab telah memposisikan pemberi bantuan hukum itu jejajar dengan penegak hukum yaitu hakim. Hal ini sesuai dengan undang-undang advokat nomor 18 tahun 2003 pasal 5 yang menyatakan bahwa kedudukan advokat setara dengan penegak hukum lainya. Namun para ulama madzhab lebih menekankan pada ketatnya kualitas untuk merekrut seorang penegak hukum dan juga pengawasan terhadap kinerja para penegak hukum yang dirasa kurang saat ini di Indonesia khusunya bagi advokat.

Kedudukan advokat yang sekarang ini semakin kuat tenyata tidak sepenuhnya berkontribusi positif dalam proses penegakkan hukum di Indonesia. Tidak sedikit praktik yang dilakukan oleh para advokat hitam yang seolah mereka mendapat angin segar untuk melakukan praktik mafia hukum di negara ini. Advokat makin semena-mena dan menyelewengkan pekerjaan yang mulia tersebut hanya untuk mendapatkan keuntungan secara pribadi. Bahkan tak jarang advokat menjadi otak dari tindakan melawan hukum yang dilakukan klienya.

Namun disisi lain keberadaan advokat sangat diperlukan, karena advokat sebagai profesi yang mulia ini dapat memberikan advokasi dan bantuan hukum terhadap masyarakat awam yang hendak mencari keadilan.

\footnotetext{
32 A. Rahmat Rosyadi, dan H. M. Rais Ahmad, Formalisasi Syariat Islam dalam Perspektif Tata Hukum Indonesia, hal. 68
} 
Advokat sebagai pihak yang independen diluar dari lembaga negara bisa membatu mengawasi proses peradilan di Indonesia sehingga tidak terjadi penyelewengan dan tindakan semenamena oleh pemerintah. Kenyataan inilah menjadi dilema dan perdebatan dikalangan ahli tentang keberadaan advokat sebagai penegak hukum dalam sistem hukum di Indonesia.

Jika kita melihat pandangan Islam terkait kedudukan advokat maka seharusnya yang menjadi titik tekan dalam aturan perundangundangan adalah bagaimana memperketat proses pengankatan seorang advokat. Seorang advokat bukanya hanya seorang yang paham dan ahli dibidang hukum namun kualitas moral harus juga menjadi prioritas utama. Karena sesungguhnya munculnya praktik mafia hukum yang dilakukan oleh advokat hitam itu adalah bukan dikarenakan kualitas intelektual mereka yang buruk, namun kualitas moral mereka yang bermasalah sehingga keserakahan yang mendominasi dalam dirinya. Untuk itu kualitas moral seorang advokat menjadi prioritas utama demi melahirkan advokat-advokat baru dimasa yang akan datang yang lebih amanah. Mungkin bisa juga ditambahkan dalam materi pendidikan advokat tentang moral dan agama yang selama ini belum ada sehingga dapat memperkuat kualitas moral para calon advokat nantinya.

Selain ketanya kualitas seorang penegak hukum, islam juga menekankan pada pengawasan terhadap kinerja para penegak hukum khususnya dalam hal ini adalah seorang advokat. Karena kita tahu kejahatan itu bukan hanya niat dari pelaku namun karena adanya kesempatan dan ringanya sangsi yang dijatuhkan kepada pelanggar hukum. Di Indonesia pengawasan terhadap kinerjanya advokat inilah yang masih sangat lemah dan harus perlu diperbaiki. Dalam undang-undang dijelaskan bahwa kerja advokat diawasi oleh lembaga asosiasi advokat resmi namun faktanya organisasi advokat hingga saat ini masi mengalami perselisihan antara PERADI dan KAI yang semuanya mengaku sebagai organisasi resmi advokat. Jadi sistem pengawasan kerja advokat ini harus menjadi perhatian juga agar bisa mencegah praktik-praktik negatif yang dilakukan advokat sebagai penegak hukum.

Berbicara tentang relevansi penerapan hukum islam khususnya tentang pandangan
Islam tentang kedudukan advokat penulis berkesimpulan bahwa sangat relevan jika pandangan Islam ini bisa di adopsi dan dijadikan hukum positif di Indonesia. Islam mengajarkan untuk senantiasa meningkatkan kualitas moral dari setiap manusia demi terciptanya tatanan kehidupan yang harmonis. Sebagus apapun peraturan itu jika oknum-oknum pelaku aturan tersebut memiliki moral yang buruk maka aturan tersebut tidak ada manfaatnya. Meskiun banyak perdebatan di internal Islam sendiri tentang penerapan hukum Islam namun penulis berangkapan bahwa aturan hukum Islam itu lebih mengutamakan nilai-nilai bukan simbolsimbol keagamaan jadi sangat penting untuk para ahli hukum dinegara ini untuk mengkaji hukum Islam untuk menggali hukum yang relevan untuk diterapkan di Indonesa.

Selama ini hukum di dinegara ini mayoritas mengadopsi hukum-hukum dari barat. Keberadan hukum Islam sangatlah minim kecuali dalam peradilan agama Islam, padahal ajaran Islam itu sangatlah luas dan menyeluruh. Didalam Islam bukan hanya mengatur hal-hal yang sifatnya privat namun juga kebijakan-kebijakan publik dan juga ketatanegaran sehingga para ahli hukum dan juga syari'ah menjadikan hukum Islam sebagai salah satu rujukan utama dalam menetapkan hukum positif itu akan sangat mebantu terwujudnya tatanan hukum yang baik dimasa yang akan datang terlebih lagi mayoritas penduduk di negeri ini adalah muslim.

\section{Kesimpulan}

Berdasarkan uraian -uraian diatas dapat ditarik beberapa kesimpulan sebagai berikut: Dalam Islam sesungguhnya tidak mengenal kata advokat namun dalam Islam ada lembaga pemberi bantuan hukum yang secara fungsi hampir sama dengan fungsi advokat, lembaga tersebut adalah hakam, mufti dan mushalihalaih. Jika diliat dari ketiga fungsi lembaga tersebut sama dengan fungsi advokat selaku pemberi jasa bantuan hukum sebagaimana yang ada dalam undang-undang advokat nomor 18 tahun 2003.

Para ulama fiqih empat mahzab telah bersepakat mensejajarkan kedudukan lembaga pemberi bantuan hukum sebagai penegak hukum yaitu hakim sebagaimana pasal 5 undang-undang nomor 18 tahun 2003 tentang advokat yang memposisikan advokat sejajar 
dengan penegak hukum lainya. Karena keberadaan lembaga pemberi bantuan hukum itu adalah profesi yang sangat mulia yaitu turut memperjuangkan keadilan yang seadil-adilnya.

Pensejajaran lebaga bantuan hukum dengan penegak hukum yang lain tidak bisa dipahami hanya sebatas itu, karena para ulama mazhab juga menyertai dengan tingginya standar kualitas seorang pemberi bantuan hukum, bukan hanya secara intelektualitas namun juga secara moral. Tidak semua orang bisa berprofesi menjadi pemberi bantuan hukum, bahkan para ulama menyamakan standar seorang pemberi bantuan hukum dengan standar kualitas hakim. Selain tingginya setadar kualifikasi profesi ini para ulama madzhab juga sangat mengutamakan pengawasan terhadap kinerja pemberi bantuan hukum agar tidak terjadi hal-hal yang tidak diinginkan.

Penulis beranggapan sangat relevan jika pandangan Islam terkait kedudukan pemberi jasa bantuan hukum dalam hal ini adalah advokat, karena seharusnya pesejajaran advokat sebagai penegak hukum tidah bisa berhenti disitu saja namun harus disertai kualitas seseorang yang berprofesi tersebut juga pengawasan terhadap kinerja para pemberi bantuan hukum dalam praktiknya sehari-hari

\section{Saran}

Berdasarkan kajian yang penulis lakukan tentang pandangan Islam terhadap kedudukan advokat dalam pasal 5 undangundang nomer 18 than 2003 tentang advokat, bahwa perlu adanya revisi terhadap undangundang tersebut karena pensejajaran keddukan advokat harus disertai dengan peningkatan setandar kualitas seorang advokat itu sendiri dan juga sistem pengawasan yang lebih baik. Hal ini harus diatur dalam undang-undang dengan tegas untuk meminimalisir adanya penyelewengan yang dilakukan oleh advokat dalam prakteknya.

Untuk para ahli hukum sudah seharusnya menjadikan hukum Islam sebagai salah satu rujukan untuk membentuk aturan perundang-undangan yang selama ini mayorias masih didomonasi denga aturan hukum barat. Akan lebih efektif kiranya jika dalam membuat hukum atau aturan perundang-undangan di Indonesa ini dengan mengambil inspirasi dari hukum-hukum Islam sebagai ajaran yang syumul mengingat mayoritas penduduk bangsa kita ini adalah muslim, namun ini masih perlu pengkajian lagi yang lebih mendalam.

\section{DAFTAR PUSTAKA}

As-Shiddieqy, T.M Hasby,Peradilan dan Hukum Acara Islam, Semarang: PT Pustaka Rizki Pura, 1997.

Az-Zuhaili, Wahbah,Fikhul Islam waadilatuh terjemahan oleh Abu Hayyie al-Kattani dkk jilid 8, Jakarta: Gema Insani press 2011.

Darmodiharjo, Darji dan Shidarta, Pokokpokok Filsafat Hukum, (Jakarta: PT. Gramedia Utama, 2000.

Frans Hendra Winarta, Avokat Indonesia Citra, Idealisme dan Keprihatinan, Jakarta: Sinar Harapan, 1995.

Ishaq, Pendidikan Keadvokatan, Jakarta: Sinar Grafika, 2010.

Manan, Bagir, Kedudukan Penegak hukum dalam sistem ketatanegaraan Republik Indonesia, Jakarta: Varia Peradilan ke XXI No.243 Februari, 2006.

Rampe, Rampau,Hukum Praktek Advokat, Jakarta: Gramedia Widiasarana Indonesia, 2001.

Rosyadi, Rahmad dan Siti Hartati, Advokat dalam Perspektif Islam dan Hukum Positif, Jakarta: Ghalia Indonesa, 2002.

Rosyadi, A. Rahmad dan H. M. Rais Ahmad, Formalisasi Syariat Islam dalam Perspektif Tata Hukum Indonesia, Bogor: Ghalia Indonesia, 2006.

Pandu, Yudha,Klien dan Penasehat Hukum dalam Perspektif Masa Kini Jakarta: PT. Abadi Jaya, 2001.

Sabiq, Sayyid, Fiqih Sunnah (terjemahkan oleh nor Hasanuddin, LC, MA, DKK) jilid 4, Jakarta: Pena pundi aksara, 2007. 
200 | Adib Khoirul Umam, kedudukan Advokad dalam pasal 5

Sinaga, V. Harlen,Dasar-Dasar profesi Advokat, Jakarta: PT. Gelora Aksara Pratama, 2011.

Sekripsi:

Website:

Survey LSI, "Kepuasan Masyarakat terhadap kinerja penegak hukum”, www.antikorupsi.org, diakses tanggal 25 Januari 2014

Suara Pembaharuan, "Jumlah Advokat di Indonesa Makin Banyak Penegakan Hukum di Indonesia Hancur" http://www.suarapembaruan.com/home/j umlah-advokat-hitam-makin-banyakpenegakan-hukum-di-indonesiahancur/35996 diakses tanggal 29 Januari 2014 .

Arskal, Salim. Penerapan Syariat Bukan Negara Islam, http://www.islamlib.com diakses tanggal 23 Februari 2014 